\title{
30 years of Nursing in Collective Health
}

\author{
Emiko Yoshikawa Egry', Lucia Yasuko Izumi Nichiata" \\ 'Nursing School of Universidade de São Paulo. Full Professor, \\ Senior of Department of Nursing in Collective Health. São Paulo, Brazil. \\ "Nursing School of Universidade de São Paulo. Associated Professor, \\ Chief of Department of Nursing in Collective Health, admnistration 2016-2018. São Paulo, Brazil.
}

\begin{abstract}
How to cite this article:
Egry EY, Nichiata LYI. 30 years of Nursing in Collective Health. Rev Bras Enferm [Internet]. 2018;71(Suppl 1):463-4. [Thematic Issue: Contributions and challenges of nursing practices in collective health] DOI: http://dx.doi.org/10.1590/0034-7167-201871sup101
\end{abstract}

It is celebrated 30 years of the official launch, in Brazil, of the Nursing in Collective Health, a field of theories and practices supported by the historical and dialectical materialism. Nothing is more instigating than bringing to readers the special edition of REBEn called "Contributions of Public Health to nursing practice". In this editorial, it is questioned: have we been loyal to the original suppositions of the theorical part?

The question brings a comprehensive, committed and empirically proved research; therefore, in this editorial, we will highlight only the general impressions. Firstly, can be noted that the theorical field has been suffering, worldwide, a shrinkage or even a certain trivialization of what has been called Collective Health.

To understand the power of the original suppositions is necessary to check the source: it is mandatory to revisit the late 1970s, when the Movements opposite to the dictatorial regimen rebelled against the social and political situation, compelling the necessary change in the forms how society interact. The Collective Health, a theorical and practical field, support these Movements, exposing, debating and broaden the quest for better work and life conditions to all Brazilians. For technical professions like Nursing, the understanding about its work object, the reconnection of the work tools to it in the perspective of the sick-disease process understanding was essential, as a phenomenon socially produced and interpreted.

The Department of Nursing in Collective Health of the Nursing School of Universidade de São Paulo (University of São Paulo), founded in 1987, with this first designation, was inspired by theorical and epistemological bases of distinguished Latin-American thinkers*. As an objective, the Department sought for a gradual overcoming of the functionalist perspective, hegemonic in health, becoming the critical and emancipatory perspectives important, based on historical and dialectical materialism foundations ${ }^{(1)}$.

As a milestone for the expansion of the Nursing in Collective Health thinking in Brazil, it is stood out the $41^{\text {st }} 1989$ Brazilian Nursing Congress in Florianópolis. It was extensively argued in this congress the beginning of the last decade of the XX century, the perspectives and challenges to the Nursing from the enactment of the Citizen's Constitution and the forming of the Unified Health System (SUS). The need for development of new

* Jaime Breilh and Edmundo Granda (Equator), Asa Cristina Laurell (Mexico), Mário Testa (Argentina), Giovanni Berlinguer (Italy). In Brazil, Cecília Donnângelo, Graciete Borges da Silva, Sérgio Arouca, Emerson Merhy, Maria Cecília de Souza Minayo, Ricardo Bruno Mendes Gonçalves, Marcio Almeida, among many others. As institutions, is important to highlight the Centro Brasileiro de Estudos da Saúde (Brazilian Center for Health Studies, CEBES), the Associação Paulista de Saúde Pública (São Paulo's Public Health Association, APSP), the Associação Brasileira de Pós-Graduação em Saúde Coletiva (Brazilian Association of Post-Graduate in Collective Health, Abrasco) and the Associação Brasileira de Enfermagem (Brazilian Nursing Association, ABEn). Specifically in the contribution to the Nursing in Brazil and in Latin-America, Raimunda Medeiros Germano, Maria Cecília Puntel de Almeida, Semiramis Melani Melo Rocha, Abigail Moura, Roseni Rosângela de Sena, to cite only the few most highlighted ones that do not work in our Institution. 
researches challenging the hegemony of the dominant positivism in life sciences; the recognition of a social determination in health in the health process; the recognition of the functionalist perspective of Nursing, especially in the public health field, in which we were shaped with a very technical and fractional bias; the breach with authoritarianism in the practical care and the radicalism in the confrontation of expansion and consolidation of the neoliberal economic model.

It has been 30 years and the field expanded in Brazil and in Latin-America, and much was enhanced in the working processes tools of Nursing. Hundreds of theses and essays were defended; many researches have been carried out, especially seeking to improve intervention tools in order to transform the objective reality. The Collective Health categories have deepened, such as: social class, gender, generation and ethnicity/race. It has been deepened as well the philosophy-based phenomena: admission, violence, health and Nursing cares, emancipation, health work, work processes, care processes, in view of the homogeneous social groups, health needs, both social and health fragilities, among others. The Nursing Collective Health thinking has bloomed in other education and research institutions in Brazil and in other countries. It has won a place in the sun in the list areas of Nursing in the CNPq: the Collective Health as a subarea with enough yields to be so, just like the other subareas.

But have we been loyal to the last name? We do not think so, at least not fully; and not even to the name, Nursing in Collective Health. Dialectical and historical researches that allow the construction of projects to overcome contradictions seem to be insufficient and limited by expliciting the totality and part of the phenomenon that may suffer changes.

Critical reflection; reflective and emancipatory dynamicity lack in our projects. The hegemonic imperative of the scientific production's avalanche has been the point of our studies and actions. Public Universities face the commercialization of education and research, as well as scientific promotion. The country has lost its path: education and health are treated as salable products; did not take responsibilities by not creating State policies to meet the needs of health and education.

Now we are surrounded by processes that do not promote substantive criticism in our society, universities and in the Nursing. A strong Movement must be created for realignment. Based on the speech of Jaime Breilh ${ }^{(2)}$, health actions will respond to the hegemonic political projects of the capitalist State, disguised with answers to social demands. The excuse given is that this is the best for "population". The conflict in the studies is only the formal logic not the dialectical logic, what prevents us from seeing overcoming. For this strong Movement, we must restate theorical suppositions of Collective Health ${ }^{(3-4)}$ which means admitting that in the society there is a capital imposition and it results inequality practices, refusing the idealistic concept of an equal society. It also means assuming the politics in the health practice, denying its own scientific impartiality.

That in the forthcoming years we could produce what is socially desired and profiled, ethically, in collective processes of a strict interpretation of objective reality of our yields and work.

\section{REFERENCES}

1. Entrevista: Jaime Breilh. Trab Educ Saúde[Internet]. 2015[cited 2017 Dec 18];13(2):533-40. Available from: http://www.scielo.br/pdf/tes/v13n2/es_1981-7746-tes-13-02-0533.pdf

2. Egry EY. Saúde Coletiva: construindo um novo método em Enfermagem. São Paulo: Ícone; 1996.

3. Mesquita AJRC. Ricardo Bruno: história, processos sociais e práticas de saúde. Ciênc Saúde Colet[Internet]. 2015[cited 2017 Dec 18];20(3):905-12. Available from: http://www.scielo.br/pdf/csc/v20n3/1413-8123-csc-20-03-00905.pdf

4. Carvalheiro JR, Heimann LS, Derbli M. (Orgs.). O social na epidemiologia: um legado de Cecília Donnangelo[Internet]. São Paulo: Instituto de Saúde, 2014[cited 2017 Dec 18]. 156 p. Available from: http://www.saude.sp.gov.br/resources/ instituto-de-saude/homepage/temas-saude-coletiva/pdfs/temas_em_saude_coletiva_16.pdf 